\section{Informal backyard rentals through a social sustainability lens - a case study in Oudtshoorn, South Africa}

\author{
Louis Lategan \& Juaneé Cilliers
}

DOI: http://dx.doi.org/10.18820/2415-0495/trp74i1.6

Revised May 2019; Published 30 June 2019

${ }^{*}$ The authors declared no conflict of interest for this title or article.

\begin{abstract}
Social sustainability is a significant field of research in post-apartheid South Africa, given the challenges and inequalities faced, evidenced in urban landscapes where millions reside in informal settlements and informal backyard rental accommodation. This article investigates the informal backyard rental phenomenon in South Africa through a social sustainability lens, focusing on a case study in Bridgton and Bongolethu, Oudtshoorn. Qualitative and quantitative research findings unveil several features in support of social sustainability framed by familial connections between landlords and backyard tenants. The article also uncovers certain challenges presented by informal backyard rentals and social sustainability, predominantly related to the quality of structures and certain social concerns. In its totality, the article provides a contextualised perspective on social sustainability in the informal backyard rental sector and provides the planning community and other decision makers with a more nuanced understanding of the complexities and potentials that may underpin it in small town South Africa and beyond.
\end{abstract}

Keywords: Social sustainability; low-income housing; informal backyard rental

\section{INFORMELE NEDERSETTINGS EN AGTERPLAASVERHURINGS DEUR 'N SOSIALE VOLHOUBAARHEIDSLENS - 'N GEVALLESTUDIE IN OUDTSHOORN, SUID-AFRIKA}

Sosiale volhoubaarheid is ' $\mathrm{n}$ beduidende navorsingsveld in post-apartheid Suid-Afrika gegewe die uitdagings en ongelykhede wat veral in stedelike gebiede in die gesig gestaar word waar miljoene in informele nedersettings en informele agterplaasverhurings gehuisves word. Hierdie artikel ondersoek die informele agterplaasverhurings verskynsel in Suid-Afrika deur 'n sosiale volhoubaarheidslens gefokus op 'n gevallestudie in Bridgton en Bongolethu, Oudtshoorn. Kwalitatiewe en kwantitatiewe navorsingsbevindinge dui op verskeie eienskappe ter ondersteuning van sosiale volhoubaarheid, gerugsteun deur familiële verbintenisse tussen verhuurders en hul agterplaashuurders. Die artikel onthul ook sekere uitdagings tot sosiale volhoubaarheid wat deur agterplaasverhuring teweeg gebring word, hoofsaaklik toegeskryf aan die kwaliteit van strukture en ander sosiale kwelpunte. In die geheel, verskaf die artikel 'n gekontekstualiseerde blik op sosiale volhoubaarheid en die informele agterplaasverhuringsektor en bied aan owerhede en ander besluitnemers 'n meer genuanseerde begrip van die kompleksiteit en potensiaal wat die sektor in kleiner dorpe en die res van Suid-Afrika inhou.
Sleutelwoorde: Sosiale

volhoubaarheid; lae-

inkomste behuising;

informele agterplaasverhuring

\section{KHIRO E SENG MOLAONG \\ YA MATLO A KA MORAO \\ DIJARETENG, RE SHEBILE \\ POLOKEHO YA SETJHABA - \\ THUTO YA MEHLALA KA HARE HO OUDTSHOORN, SOUTH AFRICA}

Polokeho ya setjhaba ke lekala le bohlokwa la diphuputso dinakong tse ka mora kgethollo ya merabe Afrika Borwa, ka lebaka la diphepetso le ho se lekalekane ho bileng teng; ho banahetseng meralong ya ditoropo, moo teng dimilione tsa batho di dulang dibakeng tse seng molaong le ho hira bodulo bo seng molang ka morao dijareteng tsa batho. Atikele ena $e$ fuputsa tabahadi ena ya khiro e seng molaong ya ka moraong dijareteng Afrika Borwa, ka ho sheba polokeho ya setjhaba; etsepamisitse maikutlo hodima thutong ya mehlala ka hare ho Bridgton le Bongolethu, Oudtshoorn. Diphumano tsa diphuputso tsa boleng le tsa lebadi (Qualitative and quantitative research) di hlahisa dibopeho tse mmalwa bakeng sa tshehetso ya polokeho ya setjhaba, di sirelleditswe ke dikamano dipakeng tsa monga sebaka le bahiri ba dulang ka morao jareteng. Atikele ena hape e utolla diphepetso tse itseng tse tliswang ke khiro e seng molaong ya ka morao dijareteng le polokeho ya setjhaba, haholoholo e amanang le boleng ba sebopheho le dingongoreho tse itseng tsa setjhaba. Ka kakaretso, atikele e fana ka mohopolo o boemong ba bolokeho ya setjhaba khirong e seng molaong ya ka morao dijareteng, mme e fa setjhaba se ralang meralo le batho ba bang ba etsang diqeto; kutlwisiso e fapaneng hannyane ya diphetoho le dikgonahalo tse ka hlahang ditoropong tse nnyane tsa Afrika Borwa le ho feta.

\section{INTRODUCTION}

This article focuses on social sustainability in a relatively under-researched niche of South Africa's housing market (Marais \& Cloete, 2014: 50), the informal backyard rental (IBR) sector. Although the IBR sector is expanding rapidly (Lemanski, 2009: 473; Shapurjee et al., 2014: 20), relatively

Dr Louis (L.G.) Lategan, Unit for Environmental Sciences and Management, North-West University, Potchefstroom, 2520, South Africa. Phone: 0182992400, e-mail: <latlou.info@gmail.com> DOI: https://orcid.org/0000-0002-8969-6766

Prof. Juaneé (E.J.) Cilliers, Unit for Environmental Sciences and Management, North-West University, Potchefstroom, 2520, South Africa. Phone: 0182992400, e-mail: <juanee.cilliers@nwu.ac.za> DOI: https://orcid.org/0000-0002-8581-6302 
few studies have researched the phenomenon. A dearth of knowledge on the social dynamics that anchor the sector within South Africa's low-income communities has had negligent impacts in the past (Lemanski, 2009: 483; Rubin \& Gardner, 2013: 22). Certain pilot interventions localised in metropoles have concentrated on the financial opportunities small-scale letting may afford landlords; interfered in tenant selection processes, and formalised structures and rental agreements (Watson, 2009: 17). These invasive tactics proved unsuccessful, were met with protest, and caused displacement, partly because certain landlords and tenants were related (Carey, 2009: 2; Lategan, 2017: 352). The bulk of existing research has focused on IBRs in larger cities or metros in pace with the foci of past pilots (Zweig, 2015: 2). As such, "little is known about informal rental conditions in smaller SA towns" (Rubin \& Gardner, 2013: 6) where IBRs are also common, but socioeconomic conditions diverge from contexts affecting IBRs in larger cities. This article speaks to these shortcomings by investigating the premise that IBRs in smaller towns may demonstrate a more prolific inclination towards rentals based on social and familial links and less on financial exchanges among unrelated stakeholders than in larger cities. This premise does not deny the existence of familial links in large cities or that some IBRs in smaller towns function on commercial principles.

Research draws on empirical data from a case study of IBRs in the small- to medium-sized town of Oudtshoorn and its Bridgton and Bongolethu Townships. Findings confirm that the majority of landlords and their informal backyard (IB) tenants are related in the case study. The effects of these connections were expounded in a synthesis on IBRs and social sustainability evaluating case study findings according to a conceptual framework based on a literature review.

Results affirmed an IBR sector that supported various principles related to socially sustainable communities based mostly on supportive and amiable landlord-tenant relationships framed by familial connections, and identified detriments related to the physical environment and other social afflictions.

The article's contributions are manifold. It addresses the lacking focus on IBRs in smaller towns; confirms familial links between landlords and tenants as dominant in the small town case study; suggests that findings may be generalised for similar small town contexts and considered as representative for a proportion of the IBR sector in larger cities; substantiates motivations to maintain and support IBRs on grounds of social sustainability; reiterates the importance of nuanced approaches that do not undermine existing landlord-tenant relationships and existing contributions towards more socially sustainable communities, and underscores certain challenges to be addressed in national and local policies.

\subsection{Coming to terms with social sustainability and socially sustainable communities}

This article defines social sustainability based on key elements identified in the literature and in terms of a sustainable community (Bramley et al., 2006; Dempsey et al., 2009). Accordingly, a socially sustainable community may provide a diversity of current and future residents with a just opportunity to access basic services in stable, safe and secure environments conducive to good health where they may live their entire lives and find support in cohesive networks that facilitate civic involvement and political engagement; a shared sense of place, quality of life and wellbeing (Davidson \& Wilson, 2009: 5; Glasson \& Wood, 2009: 284; Dempsey et al., 2009: 3; Mak \& Peacock, 2011: 3; Woodcraft, 2012: 31; Dixon \& Woodcraft, 2013: 478;

Goosen \& Cilliers, 2018: 260). Social sustainability is furthermore related to the interconnected and equally disputed concepts of social cohesion and social capital (Cloete, 2014: 6; Bwalya \& Seethal, 2016: 41). This article delineates social cohesion as the extent to which a society is socially just, united in shared interests, circumstances and identity, being functional, providing positive social relationships within a bonded network and environment that allows its members to flourish in solidarity, resulting in social capital (Cortese et al., 2014: 2052; Bwalya \& Seethal 2016: 41; Carrasco \& Bilal, 2016: 128; Obremski \& Carter, 2019: 171). Social capital is synthesised as a resource produced by participating in social networks and civic institutions, supported by trust that accommodates reciprocal exchanges, mutual support and collective action to achieve communal objectives (Matthews \& Besemer, 2015: 189; Carrasco \& Bilal, 2016: 128; Opp, 2017: 300). These broad definitions are not all-inclusive or indisputable, but provide guiding features towards an understanding of more socially sustainable communities as point of departure to reflect on South Africa's IBR sector (see Table 2).

From these definitions, links between social sustainability and the physical environment become obvious. Social activity is interrelated with the physical context in which it transpires (Dempsey et al., 2009: 7). Accordingly, social sustainability has provided a focus for planning research, policy and practice, emphasising the social outcomes of aspects such as housing (Dixon \& Woodcraft, 2013; Obremski \& Carter, 2019). In planning for physical and non-physical attributes potentially conducive to more socially sustainable environments, the elements captured in Table 1 may be considered. A few elements are highlighted. Safety, a basic human need (Opp, 2017: 302) is emphasised. "Safety is the ontological foundation of sustainability in general and social sustainability in particular" (Eizenberg \& Jabareen, 2017: 1), referring to the right to be safe and adopt all measures of adaptation and security to prevent future casualties 
and physical harm. Where the built environment exhibits poor condition, people may be physiologically affected and their sense of safety disturbed (Dempsey et al., 2009: 10).

The physical environment may impact inter-generational equity, referencing the extent to which future generations will not suffer under the repercussions of the actions of the current generation (Mak \& Peacock 2011: 3; Eizenberg \& Jabareen 2017: 290) and the prospect of long-term residency, possibly spanning multiple generations. The urban environment can nurture community stability by encouraging lower residential mobility and turnover (Forrest \& Kearns, 2001: 2134; Dempsey et al., 2009: 9) as influenced by social equity referenced above, rooted in distributive justice and equality of condition in the objective appointment of resources. Social equity is often measured by the level of access provided to adequate housing, education, basic services, social infrastructure, green, cultural and recreational spaces (Dempsey et al., 2009: 5), entrenched in urban planning decisions. Table 1 captures the bulk of these elements.
Social sustainability premised exclusively on the above definition and Table 1 would indicate that it exists only in idyllic places unburdened by poverty, poor service access and poor environmental quality. Positive social activity and social order are more likely to manifest in physical environments of high quality (Dempsey et al., 2009: 5), but social sustainability is not dependant on the quality of the physical environment. The challenges centralised in places of poorer quality may act as catalysts for social cohesion (Dempsey et al., 2009: 5), encouraging communities to analyse and articulate the fulfilment of their rights (Carrasco \& Bilal 2016: 128), building social capital, and improving their environments and quality of life.

\subsection{Challenges to social sustainability in South Africa}

In South Africa, attempts to redress colonial and apartheid impacts and promote sustainable development have been restrained by several social challenges. Chief among which is inequality. Inequalities are demonstrated in official indicators such as the Ginicoefficient; physically expressed in the country's human settlements,

Table 1: Urban social sustainability associated with non-physical and physical forms

\begin{tabular}{|l|l|}
\hline \multicolumn{1}{|c|}{ (A) Non-physical elements } & \multicolumn{1}{c|}{ (b) Physical elements } \\
\hline Health, quality of life and well-being & Attractive public realm \\
\hline Social inclusion/no social exclusion & Adequate housing \\
\hline Social capital & Quality local environment and amenity \\
\hline Sense of safety & $\begin{array}{l}\text { Accessibility to services/facilities/green space/ } \\
\text { employment }\end{array}$ \\
\hline Fair income distribution & Sustainable urban design \\
\hline Social order & Neighbourhoods \\
\hline Social cohesion & Pedestrian-friendly/walkable neighbourhoods \\
\hline Community cohesion & Sufficient lighting \\
\hline Social networks & Enclosure \\
\hline Social interaction & Mixed tenure \\
\hline Sense of community and belonging & Appropriate density \\
\hline Employment & Sustainable transport networks \\
\hline Residential stability & Mixed land use \\
\hline Active community organisations & \multirow{2}{*}{} \\
\hline Cultural traditions & \\
\hline Low residential turnover & \\
\hline
\end{tabular}

Source: Constructed based on Dempsey et al. (2011); Woodcraft (2012); Dixon and Woodcraft (2013); Opp (2017)

and reflected in the outcomes of the state's subsidised housing projects which have reinforced inequalities by sourcing peripheral development locations (Croese et al., 2016: 240) often reminiscent of the sites secured for non-White South Africans under apartheid (Turok, 2016: 5), and the small size and poor quality of the units they have provided (Freund, 2010: 287; Lizarralde, 2011: 176). Approximately 2.8 million subsidised homes were delivered by 2016 (Turok, 2016: 5). Yet, millions have remained destitute, living in a growing number of informal settlements (Turok, 2012: 21) or IBRs as alternatives (Lemanski, 2009: 473; Tshangana, 2013: 4).

\section{THE INFORMAL BACKYARD RENTAL SECTOR AND SOCIAL SUSTAINABILITY}

IBRs are customarily one- or two-roomed informal structures erected of corrugated iron, metal sheets, timber, and plastic (Morange, 2002: 6; Robins, 2002: 512; Lemanski, 2009: 473) in backyards adjacent or attached to formal dwellings. Backyard tenants often face small, uncomfortable, dark, damp, permeable and inadequately ventilated structures, described as unhealthy and unsafe (Morange, 2002: 4; Lemanski, 2009: 473; Shapurjee \& Charlton, 2013: 662). IB renters may contend with such conditions to access the range of benefits backyard tenancy may present compared to informal settlements.

\subsection{The access, safety and security provided by backyard locations}

Backyard tenants often prefer the more central locations and access provided by older townships (Morange, 2002: 10; Bank, 2007: 206; Watson, 2009: 5). Many are also drawn to backyard accommodation in such localities to escape the violence and hazards correlated with peripheral informal settlements (Morange, 2002: 10; Zweig, 2015: 5). Backyard dwellings 
in the 'safer' core provide security (Gilbert et al., 1997: 139) and some stability via an increased number of vigilant residents potentially reducing chances of theft and intrusion (Carey, 2009: 11; Shapurjee \& Charlton, 2013: 661). For tenants, the proximity and connection to established landlords may reinforce a sense of moral and physical security (Morange, 2002:11) under landlord protection (Shapurjee \& Charlton, 2013: 661). Yet, backyard tenants may be comforted by a false sense of security, as crime is an omnipresent threat in South Africa (Klaaren, 2015: 552). Some argue that the structural informality of IBRs make dwellings more vulnerable to home burglaries and attacks (Meth, 2013: 547). Besides locational advantages, safety and stability perceptions, IB tenancy have been significantly motivated by the probability of access to basic services.

\subsection{Opportunities to access basic services}

The majority of IB renters enjoy service access

(Gilbert et al., 1997: 139; Gunter 2014: 97) using sanitation facilities and water in main dwellings (Govender et al., 2011a: 339), connecting electricity informally (Lemanski, 2009: 477), and using refuse bins provided to landlords (Govender et al., 2011b: 32). Yet, service access is not universal or consistent (Tshangana, 2013: 7), ascribed to restrictions imposed by landlords, limited or damaged facilities, overcrowding and power outages (Lemanski, 2009: 477; Govender et al., 2011a: 339; Zweig, 2015: 6).

\subsection{Demographic trends for landlords and backyard tenants}

IBR landlords and tenants are not homogeneous, yet broad patterns have been observed in existing literature (Watson, 2009: 5). Although a range of age groups occupy IBRs (Gilbert et al., 1997: 135; Lemanski, 2009: 476; Zweig, 2015: 5), tenants are commonly younger than landlords (Gilbert et al., 1997: 135; Bank, 2007: 213; Watson, 2009: 5; Rubin \& Gardner, 2013: 6; Shapurjee \& Charlton, 2013: 658; Gunter, 2014: 99; Zweig, 2015: 5) who may be well established residents who are already or almost retired (Rubin \& Gardner, 2013: 31). Tenants and landlords are often single females (Gilbert et al., 1997: 139; Bank 2007: 213; Gunter 2014: 99), indicating a gendered slant in supplyand demand (Rubin \& Gardner, 2013:31). Several studies have shown tenant households to be smaller than those of landlords (Gilbert et al., 1997: 135; Lemanski, 2009: 476; Watson, 2009: 5; Rubin \& Gardner, 2013: 31; Shapurjee \& Charlton, 2013: 658). Landlords and their backyard tenants regularly exhibit comparatively low levels of household income (Gilbert et al., 1997: 139;

Morange, 2002: 14; Bank 2007: 214; Shapurjee \& Charlton, 2013: 658), with tenants often presenting greater income security with permanent employment and even marginally higher incomes than landlords (Watson, 2009: 5; Rubin \& Gardner, 2013: 31; Shapurjee \& Charlton, 2013: 658).

\subsubsection{Connections between landlords and backyard tenants: Family, friends or strangers?}

Landlords and their backyard tenants are either family members or unrelated stakeholders. Certain studies localised in larger cities have shown the majority of IB tenants to be paying renters unrelated to landlords (Morange, 2002: 13; Bank, 2007: 209;

Lemanski, 2009: 476). Generalisations on landlord-tenant relationships based on business arrangements between unrelated acquaintances centred on experience in larger cities have framed many of the assumptions and pilot interventions of the past. Yet, IBRs emerged during apartheid when landlords, as tenants of the state themselves, accommodated extended family members and friends in backyards (Morange, 2002: 6; Lemanski, 2009: 473). The practice has endured in places. Tenants and landlords seem to be related more frequently in Coloured than African communities (Morange, 2002: 13; Lemanski, 2009: 474). Related tenants likely remunerate landlords in kind and not cash (Lemanski, 2009: 473; Shapurjee \& Charlton, 2013: 661), or contribute to service charges (Carey, 2009: 18).

\subsubsection{Evolving and supportive landlord-tenant relationships}

Historically, the IB landlord-tenant relationship, even among relatives and friends, was regarded as exploitative and strictly for profit (Rubin \& Gardner, 2013: 17; Gunter, 2014: 98). Literature dated before the late 1990s showed that, although being relatively wealthier and better serviced than those in informal settlements, backyard tenants regularly left backyards to resettle in informal townships, blaming overcrowding, a lack of privacy, restricted service access, unstable rents, curfews, visitor and noise restrictions and eviction threats (Crankshaw, 1993: 44; Guillaume \& Houssay-Holzschuch, 2002: 94; Lemanski, 2009: 474; Lategan \& Cilliers, 2015: 851). Whereas incidences of exploitation, restricted service access and arbitrary evictions exist in selected cases (Morange, 2002: 16; Rubin \& Gardner, 2013: 17), later studies have uncovered significant shifts, as backyard rentals have increasingly provided affordable accommodation with tenure security and beneficial service access in conditions not more crowded than in informal settlements (Lemanski, 2009: 474). Relationships have been described more positively as part of supportive social networks, being fair, amiable, tolerant, and non-exploitative, framed by united consciousness, solidarity and limited conflict (Crankshaw et al., 2000: 853; Morange, 2002:1; Bank, 2007: 206; Carey, 2009: 17; Lemanski, 2009: 474; Watson, 2009: 6; Rubin \& Gardner, 2013: 7). Such social networks are significant considering the inherent vulnerabilities of backyard tenants (Morange, 2002: 15; Bank, 2007: 226; Carey, 2009: 21; Lemanski, 2009: 480; Watson, 2009: 5; 
Gunter, 2014: 98; Zweig, 2015: 2) sometimes stigmatised by a lower social status than homeowners (Zweig, 2015: 5), and a weak political voice as many authorities have engaged exclusively with registered property owners and rate payers (Beall et al., 2002). IBRs have often been characterised by a lack of representation, capacity, leadership and organisation (Lemanski, 2009: 479) that would bestow strong lobbying abilities (Morange, 2002: 3). Whilst weak representation is customary, not all backyarders have been left voiceless, as organised tenant associations have emerged to champion backyarder rights (Carey, 2009: 21; Rubin \& Gardner, 2013: 53).

Despite the optimistic descriptions attached to the landlord-tenant relationship, occasional clashes still occur, ascribed to payment, noise, water and electricity consumption disputes, maintenance problems, political tension, infringements, personal issues, a lack of communication, and rumours (Bank, 2007: 214; Carey, 2009: 19), often exacerbated by alcohol and substance abuse (Carey 2009: 19; Lemanski, 2009: 481) and cohabitating in limited space (Morange, 2002:11). Disputes have conventionally been resolved internally without legal counsel or the recourse provided by the Rental Housing Act of 1999 and the Rental Housing Amendment Bill of 2007 (Watson, 2009: 6; Mohamed, 2010: 2; Rubin \& Gardner, 2013: 18). The latter provided for Rental Housing Tribunals (RHTs) to resolve landlordtenant conflict (Mohamed 2010). However, the majority of stakeholders remain unaware of their rights and have proceeded obliviously (Watson, 2009; Gunter, 2014: 102).

\section{INVESTIGATING SOCIAL SUSTAINABILITY AND IBRS IN BRIDGTON AND BONGOLETHU, OUDTSHOORN}

Oudtshoorn, capital of the Oudtshoorn Local Municipality (OLM) in South Africa's Western Cape, is

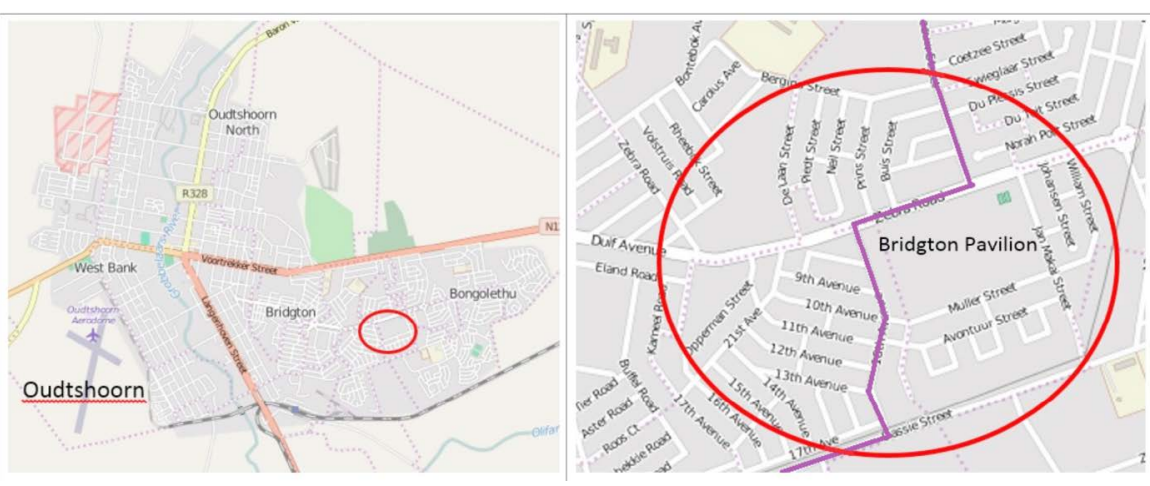

Figure 1: The Bridgton and Bongolethu case study area

Source: Lategan, 2017

home to 95933 residents, of which $77.35 \%$ are Coloured (a widely used term in post-apartheid South Africa [Adhikari, 2004]), 12.49\% White, and $9.11 \%$ African, according to Census 2011. Two prominent apartheid-era townships, Bridgton and Bongolethu house $33.73 \%$ of the OLM's total population, primarily in state-provided housing. These townships accommodate a substantial and burgeoning, but undetermined number of IBRs (Daughters, 2015), foreshadowing the informal rentals now populating the backyards of newly constructed subsidised homes in the Rose Valley extension, following an informal settlement upgrade project (Lategan, 2017: 308).

\subsection{Methodology}

The empirical research was based on a 2015 survey of 103 properties surrounding the Bridgton Pavilion, a landmark and centre of community life around which a high number of IB structures could be identified on aerial photos (see Figure 1). The Bridgton/Bongolethu survey included only properties with IBR components, with willing landlord and backyard respondents. Separate questionnaires were provided to the heads of landlord and backyard tenant households, respectively. Respondent properties were selected via convenience sampling as a non-probability sampling technique where members of the target population meet practical criteria, for example geographical proximity, easy accessibility, availability, or willingness to participate (Dörnyei, 2007).
Convenience sampling is useful when randomisation is impossible (Explorable.com, 2009). In the Bridgton/Bongolethu case, no records existed that document the presence of IBR structures from which a sample could be randomly selected.

Aerial photos showing IB structures did not provide clarity on their use for rental, commercial or storage purposes and potentially provided outdated information, as IBRs may be constructed, demolished and moved continuously. Aerial photos did, however, provide an indication of areas where informal backyarding was prominent and concentrated. Surveys were conducted assisted by chaperones who were available for limited periods. These chaperones, familiar with, and trusted by the community as police reservists, acted as guides and facilitators. There was no self-selection of respondents. It is doubtful that a random sample would have delivered drastically different results, except in feasibly reducing the number of respondents, as there was no way of identifying which households accommodated backyarders and would be available and willing to participate at the times chaperones would also be available, from which to generate a random sample. Respondents were advised on research objectives and general instructions. Informed consent was described in terms of respondents' voluntary participation and confidentiality guaranteed.

Questionnaires probed spatial, economic and social issues, with social issues reported on, in this instance. Survey questions were 
drafted in collaboration with the North-West University's Statistical Consultancy Services who also captured and analysed data using IBM SPSS. As a convenience sample instead of a random sample was used, $p$-values may be reported, but not interpreted. Furthermore, the article drew on semi-structured interviews conducted with local officials and other relevant stakeholders, cited with pseudonyms, who provided insight on matters less forthcoming in literature and existing statistics. Interviews were audio recorded and transcribed for ease of reference.

\subsection{Demographic discoveries}

Questionnaires reached 244 households, of mainly Coloured, Afrikaans-speaking members. The sample included 103 individual properties accommodating 103 main (42.21\%) and 141 (57.79\%) IB households; 103 main and 120 IBR questionnaires were completed. The 223 households represented accommodated 1 023 dwellers, with 577 (56.40\%) residents in main dwellings and 446 $(43.60 \%)$ residents in IBRs. Main dwellings housed a mean of 5.60 residents ( $s=2.928$ ), whereas IBRs housed a mean of $3.72(s=1.74)$ residents, thus substantiating trends on smaller IBR household sizes (Gilbert et al., 1997: 135; Lemanski, 2009: 476; Watson, 2009: 5; Rubin \& Gardner, 2013: 31; Shapurjee \& Charlton, 2013: 658). IBRs were mainly fabricated using corrugated metal sheeting $(97.5 \%)$, timber $(97.5 \%)$, cardboard $(16.7 \%)$, and plastics $(8.3 \%)$. IBRs have an established history in Bridgton/ Bongolethu as integral components of the community's identity and character, contributing to a sense of place that accepts informality alongside the formal. Findings showed that $74.8 \%$ of landlords (as the head of the household) were female and $25.2 \%$ male. Furthermore, $66.7 \%$ of IB tenants (as the head of the household) were male and $33.3 \%$ female, thus confirming preceding research on the dominance of female

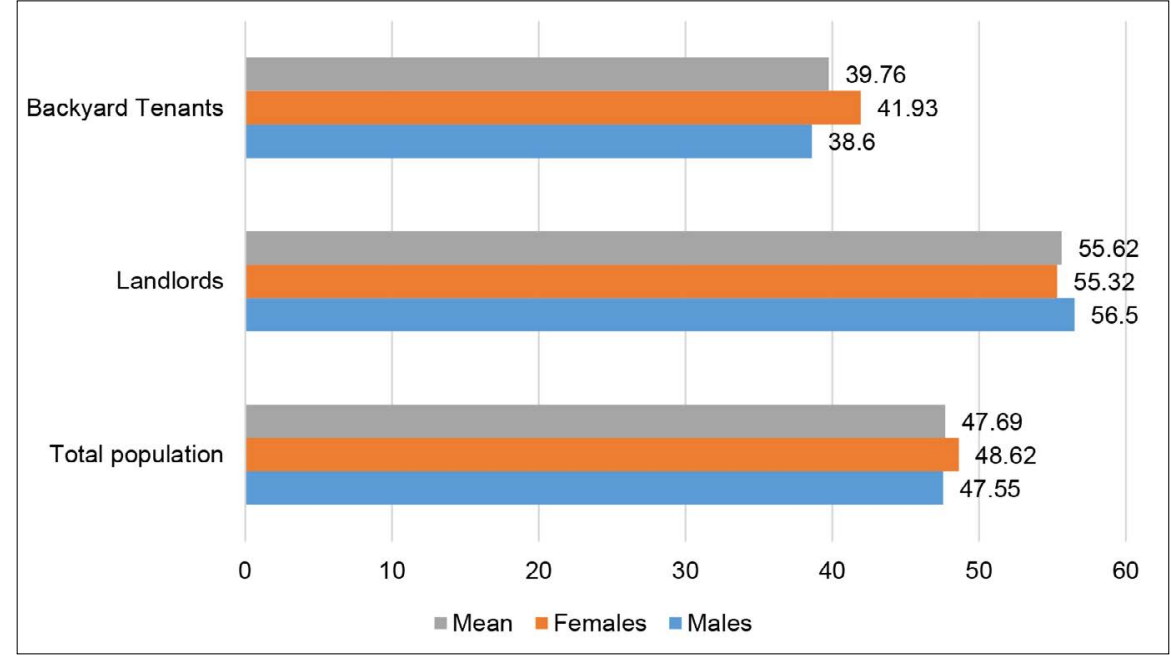

Figure 2: Mean ages of backyard tenants and landlords for both sexes in years. Source: Lategan, 2017

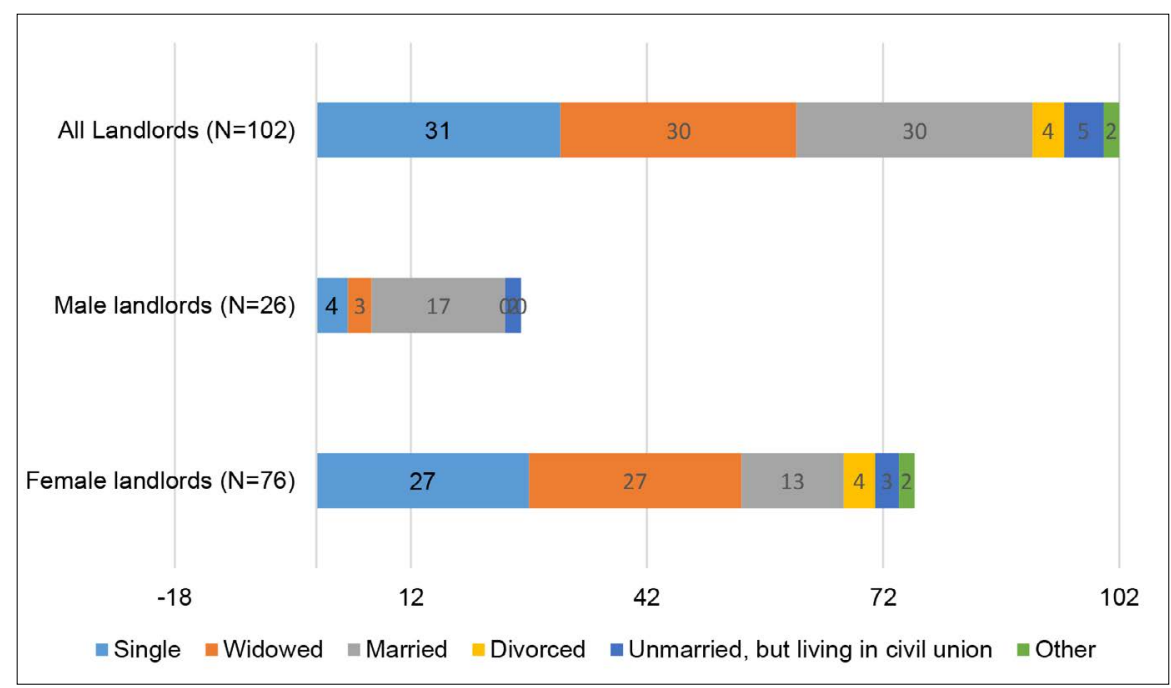

Figure 3: Landlord marital status in actual numbers

Source: Lategan, 2017

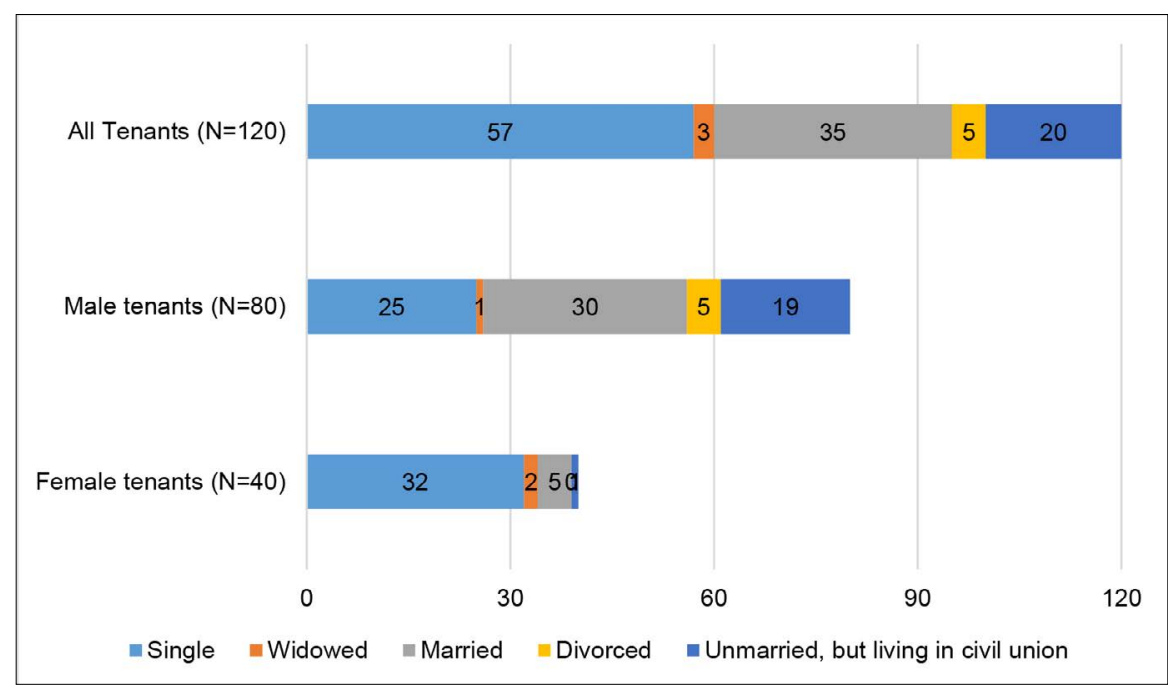

Figure 4: Backyard tenant marital status in actual numbers

Source: Lategan, 2017 
landlords (Gilbert et al., 1997: 139;

Bank 2007: 213; Rubin \&

Gardner, 2013: 31; Gunter, 2014:

99) and male tenants (Zweig,

2015: 5). Figure 2 captures mean

ages for females and males

in the total population and for

landlords and IB tenants.

Figure 2 confirmed older landlords compared to backyard tenants, as in Gilbert et al. (1997: 135);

Bank (2007: 213); Watson (2009:

5); Rubin \& Gardner (2013: 31);

Shapurjee \& Charlton (2013: 658);

Gunter (2014: 99), and

Zweig (2015: 5), in the case study

by a mean of 15.86 years.

Data revealed that $30.4 \%$ of all the landlords were single, $29.4 \%$ married and $29.4 \%$ widowed. Whereas $47.5 \%$ of the tenants were single, $29.2 \%$ married and $16.7 \%$ unwed, but cohabitating in civil unions. Figures 2 and 3 capture marital status for the head of the household for landlord and backyard tenants in actual numbers.

Figures 2 and 4 evidence that the majority of the respondents were single. Females, as the majority of landlords, were either single $(35.5 \%)$ or widowed $(35.5 \%)$. Goebel et al. (2010) posit that low-income females endure specific hardships considering poverty, illness and care-giving abilities. Female backyard tenants were also predominantly single $(80 \%)$, sharing in the troubles of female landlords. Male backyarders, as the majority, were single (31.25\%), married $(37.5 \%)$, or living in civil union $(23.8 \%)$ and, in cases of the last two, could draw on mutual resources and support. Consequently, the typical landlord was a single female in her mid-to-late 50s who accommodated a married/attached male tenant in his late 30 s. Concurring with established trends regarding older single female landlords and younger backyard tenants, it diverged for tenant sex and marital status trends established elsewhere (see Section 2.3).

The majority of the landlords (93.2\%) and backyard (86.6\%) households reported a monthly household income below R3 500. Most of them earned between R1 001 and R1 500 monthly, thus living in similar conditions and fostering a sense of solidarity, mirroring findings by Gilbert et al. (1997: 139); Bank (2007: 214); Lemanski (2009: 473), and Shapurjee \& Charlton (2013: 658). Data showed that $68 \%$ of the landlord and $1.8 \%$ of the backyard households declared pensions as the main source of income, reflecting discrepancies in landlord and tenant ages established.

In the case study, IBRs were thus dominated by single female landlords who are close to retirement age or have already retired and continue to be breadwinners and caregivers. IB landlordism is common among the elderly, because rental contributions may make homes viable for many who would otherwise have to relocate from their historical neighbourhoods to more affordable, often lower quality housing (Rubin \& Gardner, 2013: 41). IBRs offer the opportunity to lodge extended family members, often as older or married children (Zweig, 2015: 5), thus presenting opportunities to unite families (Rubin \& Gardner, 2013: 31), foster multigenerational living (Shapurjee \& Charlton, 2013: 661), and aging in a fixed location (Rubin \& Gardner, 2013: 19) with social support from backyard relatives. In Bridgton/Bongolethu, IB tenants participated in community life, belonged to civic institutions and attended local schools where they were not stigmatised or ostracised, thereby embedding themselves in the community and building extended support networks that entrench social belonging. Such links underpin a number of the characteristics that support social sustainability, as low residential turnover, enhanced social networks; civic engagement, and quality of life and wellbeing identified in the literature review.

\subsection{The nature of landlord-tenant links}

In $80.8 \%$ of the backyard households, all members were related to landlords. In $12.5 \%$ of cases, only certain members shared familial connections with landlords. In $6.7 \%$ of cases, no such association was reported; $45.8 \%$ of the backyard respondents claimed to be backyarders primarily to maintain familial ties. This confirms the tendency for Coloured landlords and tenants to be related, following Morange (2002: 13), Carey (2009: 18) and Lemanski (2009: 473). Lemanski (2009: 479) theorised that, in Cape Town, many landlords as previous shack dwellers sympathised with the destitute, providing rentals as a moral imperative described by Gilbert et al. (1997: 141) as the antithesis of "classic landlord behaviour".

Results revealed that $93.1 \%$ of the landlords provided IBRs motivated by compassion and moral obligation, whereas $2 \%$ cited financial motivations, thereby reaffirming low cash rents. The $55.8 \%$ of tenants who contributed rent, paid a mean of R253.43 monthly. Tenants who did not pay cash rents contributed towards water and electricity costs $(27.3 \%)$, home maintenance $(9.9 \%)$, or domestic help to landlords (4.1\%). Cramer's $\mathrm{V}$ test for the nature of the landlord-tenant relationship, in terms of familial connection, and motivation for engaging in IBRs, yielded an effect size of 0.415 $(p=0)$, as a strong medium effect and practical visible significant association. Financial motivations were strongest where landlords and tenants were not related at all, yet compassion/social motivations dominated, regardless of the nature of the landlord-tenant connection. As nearly all landlords and tenants were related, cash rents were very low and landlords motivated by social obligations, a case could be made to define their relationship not as a rental arrangement, but merely as the manner in which extended family members are accommodated in informal extensions.

However, findings support inclusion under the informal rental umbrella, as the majority of backyard dwellings housed autonomous households almost unilaterally expected to contribute monetary or non-monetary 
assistance. Thus, it is suggested that the term IBR be widely applied to include related tenants and landlords, even when their arrangements are not premised solely on traditional rental terms, as supported by Rubin \& Gardner (2013). In the case study, these informal rental arrangements contributed towards self-reliant, organic communities that demonstrate harmony and co-operation, places of sharing (Lategan \& Cilliers 2013: 309), in which important social safety nets and social capital were manifested (Rubin \& Gardner, 2013: 31) that arguably contributed to an increased sense of security for landlords and tenants. These supportive networks are tried in times of conflict.

\subsection{Evaluating the relationship between landlords and their tenants}

Evaluating the landlord-tenant relationship in terms of conflict showed that $86.4 \%$ of the landlords reported that landlord-tenant conflict was never an issue (or so rarely that it could not be recounted); only $7.8 \%$ reported conflict once a month, whilst $5.8 \%$ reported conflict more than once a month. A substantial $75.8 \%$ of IB tenants reported that landlordtenant conflict has never been an issue (or so rarely that it could not be recounted); $10 \%$ reported conflict at least once monthly; $7.5 \%$ registered conflict more than once a month, whilst $6.7 \%$ conveyed landlord-tenant conflict occurring almost daily.

Landlords thus reported lower levels of conflict, perhaps owing to their position of power, whereas tenants, as more vulnerable stakeholders, were more sensitive to disagreements. Cramer's $\mathrm{V}$ test for the nature of the landlord-tenant relationship, in terms of familial connection and the prevalence of conflict noted by landlords, provided an effect size of $0.082(p=0.847)$ and for backyard tenants an effect size of $0.148(p=0.510)$, showing a practical non-significant association in both cases. Results thus show that the nature of the landlord-tenant

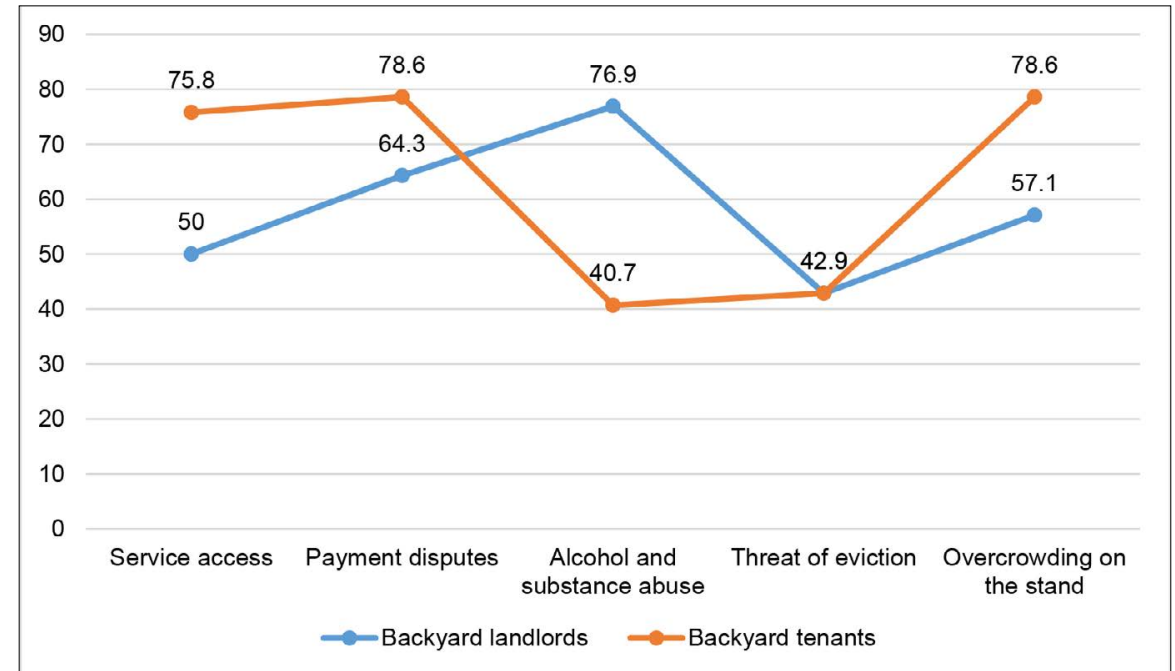

Figure 5: Comparing sources and prevalence of conflict for landlords and informal backyard tenants

Source: Lategan, 2017

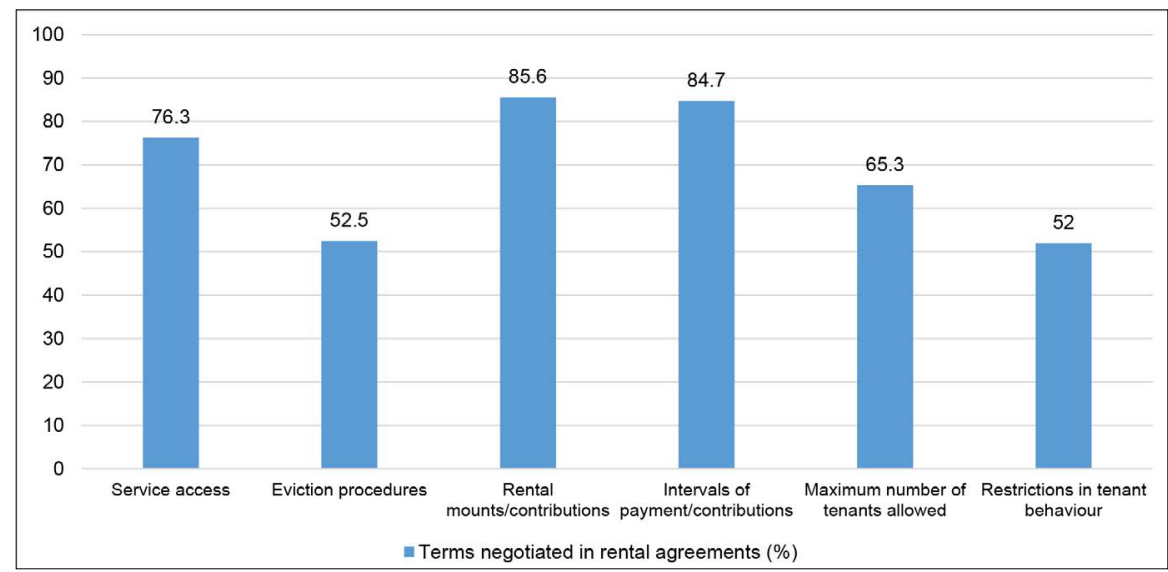

Figure 6: Terms negotiated in rental agreements (\%)

Source: Lategan, 2017

connection was not a significant predictor for level of conflict.

Figure 5 conveys that landlords and tenants experienced sources of conflict differently, with the exception of 'threat of eviction' as a low source for both parties. For all variables, excluding 'alcohol and substance abuse', backyard tenants reported higher levels of related conflict than landlords.

Backyard tenants may register increased levels of conflict regarding service access, because tenants are reliant on the access granted by landlords and are more disadvantaged by hindrances thereto; are more sensitive to payment disputes as tenants are responsible for prompt payment and held accountable; and overcrowding, because of the small size of most IBR structures and the need to venture outside into a yard shared with other tenants and landlord families.

A total of $38.8 \%$ of the landlords and $60.8 \%$ of the tenants opined that IBRs impinged on their private space in the yard. A Phi test comparing feelings of limitations on private space in the yard, due to IBRs for landlords and backyard tenants, yielded an effect size of -0.219 $(p=0.001)$, with backyard tenants more inclined to experience a lack of private space in the yard compared to landlords along a negative gradient. 


\subsection{Conflict resolution and rental terms}

Data revealed that $66 \%$ of the landlords had never sought mediation from RHTs to resolve landlord-tenant conflict, whilst $14.6 \%$ were unaware of the existence of RHTs or other formal channels. For backyard tenants, $87.5 \%$ had never approached an RHT, although some had approached other mediators. Anecdotally, the majority of the respondents seemed to confuse tribunals with unofficial mediators such as religious leaders, implying that the number of respondents who had not used tribunals may be much higher.

Results reflected that Oudtshoorn provided no local RHT. Serious cases were generally referred to George, a town located $59 \mathrm{~km}$ away (Gold, 2015). No formal representative body such as a backyard dwellers association or similar advocacy group could be identified in Oudtshoorn to lobby on behalf of IBR stakeholders or intervene in disagreements - speaking to a lack of political engagement as an important denominator in sustainable communities identified earlier.

The local housing department sometimes acted as mediator, providing rental agreement templates to capture rental terms in writing.

Respondents rarely entered a rental agreement with a written contract. In addition, $4.2 \%$ of the rental agreements were formalised on paper; $82.5 \%$ were negotiated orally, whilst $13.3 \%$ did not discuss rental terms beforehand. The prevalence of oral and the absence of agreements may reflect the dominance of familial bonds and subsequent complacency and trust that rendered a negotiated agreement obsolete.

Notwithstanding the general absence of rental agreements, data revealed that backyard tenants had occupied IBRs for a mean of six and a half years, reflecting relative tenure security. Where agreements had been negotiated, the terms and frequency of inclusion are captured in Figure 6.

Power dynamics in the negotiation of these terms varied from case to case, but landlords and backyard tenants were generally in full agreement and support of conditions included. Figure 6 illustrates that terms of rental remuneration, followed by conditions of service access took precedence in rental agreement negotiations.

An aggregate $93.33 \%$ of backyard respondents claimed access to electricity, sanitation, piped water and refuse removal accessed via landlords, indicating relative equality of condition in service access between landlords and IB tenants and distributive justice in the appointment of resources. Thus, benefiting many more impoverished citizens from the formal services provided to previous housing beneficiaries - advancing social justice.

Rules on tenant behaviour and eviction procedures were included in less than half of the negotiated agreements, resulting in ambiguous conditions conducive to disagreement and conflict (see Figure 5). Conflict was commonly attributed to poor communication between landlords and tenants (Captain, 2013) and the effects of several social ails.

\subsection{Alcohol and substance abuse, crime and safety}

Alcohol and substance abuse is common in Bridgton/Bongolethu for residents of formal dwellings and IBRs. In general, alcohol and substance abuse may be emblematic of life in poverty or ascribed to a socially imbedded predisposition (Hendricksetal.,2015:100;Zweig2015:7; Lesch \& Adams, 2016: 167). Given the homogeneous profile of respondents, dominance of familial connections and comparable household incomes proven, the article posits that there may be a marginal difference in levels of alcohol and substance abuse among landlords and backyard tenants. Backyarders are not necessarily more prone to such vices, due to their housing conditions (Captain, 2013). However, challenges related to alcohol and substance abuse may be concentrated where many impoverished individuals congregate, as facilitated by the increased population densities introduced by IB infill in the case study (Cameron, 2015; Lategan \& Cilliers 2016: 20). Furthermore, IB structures are regularly occupied by illegal alcohol vendors who contribute to the problem-drinking crisis (Lesch \& Adams, 2016: 169). No such vendors were identified in the sample. Following Figure 5, alcohol and substance abuse were cited as a foremost cause of landlord-tenant conflict. For an East London case study, Bank (2007: 17) suggested that a culture of drinking in a yard is often determined by the landlord.

Where alcohol and substance abuse are present, the proximity in which stakeholders live in IBRs often incites and increases tension (Figure 5), exacerbating the probability of violent and nonviolent crimes (Captain, 2013). Of all backyard tenants, $76.7 \%$ reported feeling secure in their backyard dwellings pertaining to their own and the safety of their possessions. Such opinions are significant, considering that $43.7 \%$ also rated crime as a daily concern. For landlords, the figure was $31.4 \%$. A Phi test for backyard tenants' perceptions of feeling safe in their dwellings and respondents claiming crime as daily concern provided an effect size of $-0.230(p=0.012)$, as a small inverse effect, with those feeling safe in their backyard lodgings slightly more inclined to report crime not being a daily concern and vice versa. A Phi test for alcohol and substance abuse as source of conflict among backyard tenants and crime as an issue of daily concern presented an effect size of $0.320(P=0.096)$, as a practical visible significant association or medium effect. Thus, where alcohol and substance abuse were problematic, backyard tenants tended to report crime as a daily concern.

Alcohol and substance abuse may hold additional penalties for safety and security. Elsewhere, backyard dwellings have been described as 
hidden (Parnell \& Hart, 1999: 367; Turok, 2012: 22), leaving vulnerable tenants such as women and children to face several injustices (Bank, 2007: 226). In the case study, alcohol and substance abuse has been linked to child sexual abuse, as inhibitions are lowered and abusers are provided with abundant opportunities (Captain, 2013), as multiple tenants of both sexes and all ages cohabit in cramped dwellings (Meth, 2013: $547)$ with limited privacy. IBRs presented a mean of $1.87(\mathrm{~s}=1.053)$ rooms per structure, commonly divided only by curtains or furniture. Backyarders are further vulnerable to electric shocks and fire-related injury or death (Wire, 2015).

\subsection{Fire threats and other backyard hazards}

Results showed that $80.8 \%$ of the backyard respondents had access to electricity and $77.5 \%$ were serviced by informal connections. As a result, electric fires commonly occur. Fires were also attributed to candles, gas stoves, impromptu heating devices and cigarettes, aggravated by a lack of knowledge on responsible fire ignition and extinction and negligence under the influence of drugs and alcohol (Case, 2015; Wire, 2015). Fossil fuels being inexpensive alternatives to electricity present indoor air pollution, fire and poisoning risks, in which children are again vulnerable. IBRs fuel fires when constructed from highly flammable materials (Meth, 2013: 546; Shapurjee \& Charlton, 2013: 662). The use of timber in $97.5 \%$ and cardboard in $16.7 \%$ of the IB structures in the case study posed significant risks. $8.3 \%$ of the IB respondents had experienced house fires in the past.

Oudtshoorn experiences approximately 60 house fires in formal and informal dwellings annually, of which approximately $68 \%$ are ascribed to IBRs (Case, 2015).

Table 2: Framework synthesising literature review and case study findings

\begin{tabular}{|c|c|c|c|c|}
\hline \multirow[t]{2}{*}{ Concept } & \multirow{2}{*}{$\begin{array}{l}\text { Components according to } \\
\text { definition }\end{array}$} & \multirow[t]{2}{*}{ Application according to case study } & \multicolumn{2}{|c|}{$\begin{array}{l}\text { Verdict towards social } \\
\text { sustainability }\end{array}$} \\
\hline & & & Contributes & Detracts \\
\hline \multirow{34}{*}{ 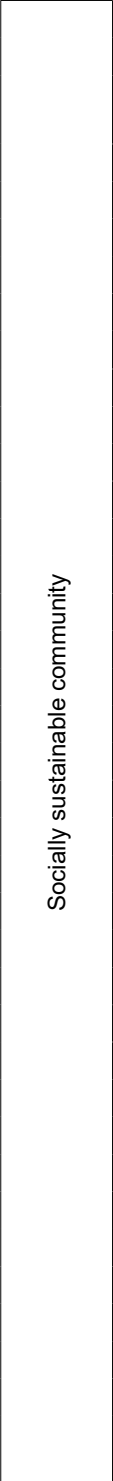 } & \multirow{3}{*}{$\begin{array}{l}\text { Diversity of current and } \\
\text { future residents }\end{array}$} & Mix of residents of different ages - intergenerational equity. & & \\
\hline & & Homogeneous racial and language profile. & & \\
\hline & & $\begin{array}{l}\text { No international migrants encountered; foreign migrants reported as IB tenants elsewhere in } \\
\text { Bridgton/Bongolethu. }\end{array}$ & & \\
\hline & \multirow{5}{*}{$\begin{array}{l}\text { Fair opportunity to access } \\
\text { basic services }\end{array}$} & High levels of service access for tenants. & & \\
\hline & & Limited conflict related to service access. & & \\
\hline & & IBRs disseminate benefits of service access and formal neighbourhoods - distributive justice. & & \\
\hline & & Shared service access - equality of condition. & & \\
\hline & & No discrimination against IB tenants in terms of service access. & & \\
\hline & \multirow{3}{*}{$\begin{array}{l}\text { Stable, safe and secure } \\
\text { environments }\end{array}$} & Most of the tenants regard residences as safe and secure. & & \\
\hline & & Stable environment - tenure security. & & \\
\hline & & More residents per yard - safety and security. & & \\
\hline & \multirow{5}{*}{ Conducive to good health } & Highly flammable structures. & & \\
\hline & & Hazardous informal electricity access. & & \\
\hline & & Health dependent on service access and quality. & & \\
\hline & & Potential for sexual and physical abuse. & & \\
\hline & & Feasible increase in alcohol/substance abusers per yard/area. & & \\
\hline & \multirow{2}{*}{ Live out their entire lives } & Many homeowners are pensioners and long-term residents supported by tenants. & & \\
\hline & & Evictions threats not considered. & & \\
\hline & \multirow{3}{*}{$\begin{array}{l}\text { Support in cohesive } \\
\text { networks }\end{array}$} & Familial bonds and long-term residency provide support. & & \\
\hline & & Limited conflict. & & \\
\hline & & Rentals motivated by compassion and social obligation. & & \\
\hline & \multirow{3}{*}{$\begin{array}{l}\text { Promote civic and political } \\
\text { engagement }\end{array}$} & No backyard dwellers' associations/other representative bodies identified. & & \\
\hline & & IB tenants attend local churches/schools/community events. & & \\
\hline & & Unity in challenging circumstances - social cohesion. & & \\
\hline & Shared sense of place & IBRs as integral components of neighbourhood/community identity. & & \\
\hline & \multirow{9}{*}{ Quality of life and wellbeing } & Lack of privacy/space in yard. & & \\
\hline & & Rental income/other contributions; affordable rental accommodation. & & \\
\hline & & IB renters attend civic institutions - partaking in public life. & & \\
\hline & & Locations in established communities provide access to facilities in proximity. & & \\
\hline & & Safety/security augmented through eyes on the yard. & & \\
\hline & & Structural inefficiencies; potentially cumbersome service access - uncomfortable. & & \\
\hline & & Family connections strengthened/expanded. & & \\
\hline & & Low conflict, positive relationships. & & \\
\hline & & $\begin{array}{l}\text { Increased population densities, alcohol/substance abuse, electrocution, fire and infection } \\
\text { risks pose health concerns. }\end{array}$ & & \\
\hline
\end{tabular}




\begin{tabular}{|c|c|c|c|c|}
\hline \multirow[t]{2}{*}{ Concept } & \multirow{2}{*}{$\begin{array}{c}\text { Components according to } \\
\text { definition }\end{array}$} & \multirow[t]{2}{*}{ Application according to case study } & \multicolumn{2}{|c|}{$\begin{array}{c}\text { Verdict towards social } \\
\text { sustainability }\end{array}$} \\
\hline & & & Contributes & Detracts \\
\hline \multirow{8}{*}{$\begin{array}{l}\frac{c}{0} \\
\frac{0}{0} \\
0 \\
\frac{0}{0} \\
\frac{0}{0} \\
\frac{\pi}{0} \\
0 \\
\infty\end{array}$} & \multirow{3}{*}{$\begin{array}{l}\text { Socially fair, united } \\
\text { in shared interests, } \\
\text { circumstances and identity; } \\
\text { functional }\end{array}$} & Community united in shared socio-economic circumstances/survival struggles. & & \\
\hline & & IBRs well-established and integrated in community. & & \\
\hline & & $\begin{array}{l}\text { IBRs often provide only accommodation option - scaffolding functionality of other aspects of } \\
\text { daily life. }\end{array}$ & & \\
\hline & \multirow{2}{*}{ Within a bonded network } & Strong familial/kinship bonds - extended network. & & \\
\hline & & Long-term residents - networks imbedded within community. & & \\
\hline & \multirow{3}{*}{ To flourish in solidarity } & IB tenants and most of the landlords remain disadvantaged - survive, rather than flourish. & & \\
\hline & & Sense of solidarity reinforced by similar levels of income. & & \\
\hline & & Many IBR units identified and growth in Rose Valley - thriving sector. & & \\
\hline \multirow{15}{*}{$\begin{array}{l}\bar{\pi} \\
\frac{\pi}{0} \\
\frac{1}{\pi} \\
\frac{0}{0} \\
\frac{\pi}{0} \\
\text { க }\end{array}$} & $\begin{array}{l}\text { Participating in social } \\
\text { networks and civic } \\
\text { institutions }\end{array}$ & Strong social networks based on familial bonds produce social capital. & & \\
\hline & \multirow{2}{*}{$\begin{array}{l}\text { Trust that accommodates } \\
\text { reciprocal exchanges, } \\
\text { mutual support and } \\
\text { collective action }\end{array}$} & Trust - lack of written/oral agreements. & & \\
\hline & & Conflict mostly resolved internally. & & \\
\hline & $\begin{array}{l}\text { Achieve communal } \\
\text { objectives }\end{array}$ & United/ supportive relationships, shared survival goals. & & \\
\hline & Attractive public realm & Poor quality environment - aesthetic qualities marred by IB dwellings. & & \\
\hline & \multirow{2}{*}{ Adequate housing } & Contested term, IB tenants enjoy tenure security, shelter and basic service access. & & \\
\hline & & Most of the IB structures physically inadequate. & & \\
\hline & $\begin{array}{l}\text { Accessibility to services/ } \\
\text { facilities/green space/ } \\
\text { employment }\end{array}$ & Potential backyard greenery occupied by IBRs. & & \\
\hline & Sustainable urban design & No provision for IBRs in township layout. & & \\
\hline & Neighbourhoods & Sense of neighbourhood. & & \\
\hline & \multirow{2}{*}{ Enclosure } & Courtyard arrangements. & & \\
\hline & & Increased security by addition of tenants. & & \\
\hline & Appropriate density & Increased densities. & & \\
\hline & $\begin{array}{l}\text { Sustainable transport } \\
\text { networks }\end{array}$ & More centrally located - marginally shorter distances to travel. & & \\
\hline & Mixed land use & No commercial/small-scale industrial IB structures encountered - opportunities presented. & & \\
\hline
\end{tabular}

Source: Own construction, 2019

The resultant fatalities average approximately eight persons per annum in Oudtshoorn, with many more treated for burns and smoke inhalation (Case, 2015). Blazes may ultimately result in widespread damage in Bridgton/Bongolethu, given the location of structures behind main homes that may allow fires to develop to an advanced stage before they are noticed (Case, 2015), echoing warnings by Zweig (2015: 6) for a Vredendal study. Fires may spread rapidly, given the dense proximity of structures.

\subsection{Health impacts and IBRs}

Articulating the connection between health and IBRs in the case study proved challenging. Patients who visited local clinics and the District Hospital did not disclose residential circumstances. Consequently, distinctions between landlord and tenant patients could not be drawn from records (Douwse, 2013).

Regarding perception, results indicated that $61.2 \%$ of the landlords and $50.8 \%$ of the IB renters believed that backyard tenants are ill more often than members of landlord households. Anecdotally, respondents seemed to regard the word 'ill' as referring only to serious and terminal conditions. Wire (2015) confirmed that Oudtshoorn's low-income groups tend to downplay 'trivial' illnesses such as colds and flu, evidenced in the low number of such cases treated by local healthcare facilities. These illnesses worsen before the patients seek medical assistance.

IBRs may have health impacts for both trivial and more serious illnesses. For example, damp and draughty conditions impact on respiratory ailments such as TB (Douwse, 2013). In relation thereto, $62.5 \%$ of the backyard tenants reported structures that were not watertight and $35 \%$ that dwellings were not ventilated. A Phi test for structures reported watertight and structures reported ventilated provided an effect size of 0.244 $(p=0.008)$, as a lower medium effect. Thus, structures reported watertight presented a small likelihood of also being reported ventilated. Structures reported not watertight were more often ventilated than structures reported ventilated were watertight. A Phi test for backyard dwellings reported watertight and backyard tenants reporting getting ill more regularly than landlords delivered an effect size of $-0.237(p=0.10)$, as a lower medium effect, indicating that where tenants were described as more ill than landlords, there was some likelihood that structures were 
not watertight. Contagious diseases may further be spread by the proximity in which backyarders live, potentially aggravated by the lack of internal walls (Zandrews, 2013; Wire, 2015).

When illness affects backyard tenants and they seek medical assistance, healthcare practitioners have testified to sympathetic bonds between landlords and tenants in Oudtshoorn, even when unrelated, evidenced when foreign migrant tenants fall ill and landlords accompany them as interpreters (Wire, 2015).

\section{SYNTHESIS}

To reflect on the theory-practice application of social sustainability and IBRs, key elements of social sustainability, socially sustainable communities and related concepts defined in the literature review were considered in relation to the case study. Table 2 dissects each definition and links each phrase/ term directly to the Bridgton/ Bongolethu case before categorising each example as either contributing to, or detracting from the social sustainability concepts provided.

Table 2 expounds and unpacks the definitions provided in this article's literature review, broadening understanding through application and exemplification. Two main deductions may be made from Table 2. First, according to the definitions provided, Bridgton/ Bongolethu's IBRs contributed towards social sustainability based primarily on supportive networks constituted by familial connections between landlords and backyard tenants that provided high levels of access to basic services. Secondly, features of the physical environment and particular social problems present in, but not restricted to IBRs detracted from the ideals of a more socially sustainable community. The aforementioned is discussed in more detail under Section 3.

\section{CONCLUSION}

This article considered several aspects of social sustainability and tangential issues such as social cohesion and social capital in the IBR sector through the lens of the Bridgton/Bongolethu case study. The literature review underscored the complexity and multifaceted nature of social sustainability and socially sustainable communities, stressing that the ideal of sustainability may be an everchanging mark never to be fully achieved. As such, misunderstood and under-researched practices that may already enhance sustainability prospects, must be investigated and supported and negative features addressed. In focusing on Bridgton/ Bongolethu, this article addressed the deficit in research focused on the informal rental contexts of smaller towns and the prospects they hold in terms of social sustainability.

Although this study did not track the growth in IBRs in Bridgton/ Bongolethu, the substantial number of IB units observed and the newly established Rose Valley extension indicate a flourishing housing subsector. IBRs continue to thrive as landlords and tenants support the sector in unity, each fulfilling important roles of support in an impoverished community. Whereas other studies have noted that familial connections between landlords and tenants do exist to varying degrees, especially in larger cities and metropolitan areas, this article shows that familial links between landlords and tenants are a leading feature of the sector in the case study. It is feasible to suggest that many IBR markets in smaller towns across South Africa may present similar connections and that familial ties should be considered as representing at least a proportion of IBR relationships in larger cities. The significance of familial connections is demonstrated when case study findings are considered within the framework provided in the preceding synthesis.

The framework evaluation demonstrated that IBRs in Bridgton/ Bongolethu support many of the social sustainability indicators captured. Without repeating Table 2, the most significant of these are identified as the close ties established between landlords and their backyard tenants; mutually supportive and relatively conflictfree landlord-tenant relationships; mixed and secure tenure; feelings of safety; excellent access to basic services; rentals provided motivated by compassion or social obligation; low residential turnover and multigenerational bonds, and IB tenants being accepted and included in the community. These deeply rooted connections enshrine a sense of solidarity, shape cohesive social networks, build social capital, improve quality of life and sense of wellbeing, thus enhancing resilience. Whilst positive attributes have been identified in the IBR market elsewhere, even where familial bonds were not dominant, familial connections embed such features more widely and deeply within the community based on relationships of reciprocal trust.

Investigating IBRs through a social sustainability lens and recognising the impacts and scope of familial connections is significant when intervention strategies are contemplated. The case study affirmed the need to support IBRs, oppose eradication objectives and consider national and local interventions from a strong social and not necessarily economic perspective as previously attempted. There is thus, a call for sensitive strategies that account for connections that surpass the traditional roles ascribed to landlords and tenants in conventional formal rental arrangements. Intrusive and disruptive interference must be avoided in favour of nuanced approaches that facilitate the functioning of certain IBR markets as social/family-based institutions and not market-led enterprises.

The Bridgton/Bongolethu case study also highlighted negative attributes (Table 2) that detract from quality of life, a sense of wellbeing and a more socially sustainable community: the quality of informal structures posed health risks; informal electricity connections and 
fire and electrocution hazards; use of fossil fuels, and certain social concerns, including alcohol and substance abuse, women and child abuse. These negatives may require targeted, context-appropriate interventions at community level to mitigate risks and improve living conditions. Providing a range of detailed recommendations falls beyond the scope of this article, but results should offer guidance towards supportive interventions that capitalise on existing contributions and address challenges towards more socially sustainable communities.

\section{ACKNOWLEDGEMENTS}

This research (or parts thereof) was made possible by the financial contribution of the National Research Foundation South Africa (NRF). Any opinion, findings and conclusions or recommendations expressed are those of the author(s). The NRF does not accept any liability in regard thereto. This article is based on a 2016 Ph.D. completed by the main author at the NorthWest University, South Africa.

\section{REFERENCES}

ADHIKARI, M. 2004. 'Not Black Enough': Changing Expressions of Coloured Identity in Post-Apartheid South Africa. South African Historical Journal, 51(1), pp.167-178. https://doi. org/10.1080/02582470409464835

BANK, L. 2007. The rhythms of the yards: Urbanism, backyards and housing policy in South Africa. Journal of Contemporary African Studies, 25(2), pp. 205-228. https://doi. org/10.1080/02589000701396298

BEALL, J., CRANKSHAW, O. \& PARNELL, S. 2002. Uniting a divided city: Governance and social exclusion in Johannesburg. London; Sterling, VA: Earthscan Publications.

BRAMLEY, G., DEMPSEY, N., POWER, S. \& BROWN, C. 2006. What is 'social sustainability', and how do our existing urban forms perform in nurturing it. Planning Research Conference. London: Bartlett School of Planning, UCL.
BWALYA, J. \& SEETHAL, C. 2016. Neighbourhood context and social cohesion in Southernwood, East London, South Africa. Urban Studies, 53(1), pp. 40-56. https://doi. org/10.1177/0042098014560502

CAMERON. 2015. Department of Housing, City of Cape Town. Informal backyard rental pilots in the City of Cape Town. Personal interview, Cape Town, 25 February 2015.

CAPTAIN. 2013. SAPD Oudtshoorn. Crime in the Bridgton and Bongolethu townships. Personal interview, Oudtshoorn, 30 April 2013.

CAREY, S. 2009. Investigation into the proliferation of low-income private rental housing supply, and the development of recommendations concerning appropriate interventions/ responses. Social Housing Foundation. Urban Landmark, pp. 1-36.

CARRASCO, M.A. \& BILAL, U. 2016. A sign of the times: To have or to be? Social capital or social cohesion? Social Science \& Medicine, 159, pp. 127-131. https://doi.org/10.1016/j. socscimed.2016.05.012

CASE. 2015. Oudtshoorn Local Municipality Fire Department. Fire risks related to informal backyard rentals in Oudtshoorn. Personal interview, Oudtshoorn, 30 September 2015.

CLOETE, A. 2014. Social cohesion and social capital: Possible implications for the common gooed: Original research. Verbum et Ecclesia, 35(3), Art \#1331, 6 pages. http://dx.doi.org/10.4102/ ve.v35i3.1331.

CORTESE, C., HAASE, A., GROSSMANN, K. \& TICHA, I. 2014. Governing social cohesion in shrinking cities: The cases of Ostrava, Genoa and Leipzig. European Planning Studies, 22(10), pp. 2050-2066. https://doi.org/10 $.1080 / 09654313.2013 .817540$

CRANKSHAW, O. 1993. Squatting, apartheid and urbanisation on the Southern Witwatersrand. African Affairs, 92(366), pp. 31-51. https:// doi.org/10.1093/oxfordjournals.afraf. a098604

CRANKSHAW, O., GILBERT, A. \& MORRIS, A. 2000. Backyard Soweto. International Journal of Urban \& Regional Research, 24(4), pp. 841-857. https://doi. org/10.1111/1468-2427.00282
CROESE, S., CIROLIA, L.R. \&

GRAHAM, N. 2016. Towards Habitat III: Confronting the disjuncture between global policy and local practice on Africa's 'challenge of slums'. Habitat International, 53, pp. 237-242. https:// doi.org/10.1016/j.habitatint.2015.11.037

DAUGHTERS. 2015. Oudtshoorn Local Municipality. Building inspectorate. Personal interview, Oudtshoorn, 7 October 2015.

DAVIDSON, K. \& WILSON, L. 2009. A critical assessment of urban social sustainability. Adelaide: The University of South Australia.

DEMPSEY, N., BRAMLEY, G., POWER, S. \& BROWN, C. 2009. The social dimension of sustainable development: Defining urban social sustainability. Sustainable Development, 19(5), pp. 289-300. https://doi.org/10.1002/sd.417

DIXON, T. \& WOODCRAFT, S. 2013. Creating strong communities - measuring social sustainability in new housing development. Town and Country Planning, November, pp. 473-480.

DÖRNYEI, Z. 2007. Research methods in applied linguistics: Quantitative, qualitative, and mixed methodologies. Oxford: Oxford University Press.

DOUWSE. 2013. Oudtshoorn Local Municiplaity. Health and sanitation conditions in Oudtshoorn's backyards. Personal interview, Oudtshoorn, 20 March 2013.

EIZENBERG, E. \& JABAREEN, Y. 2017. Social sustainability: A new conceptual framework. Sustainability, 9(1), p. 68. https://doi.org/10.3390/ su9010068

EXPLORABLE.COM. 2009.

Convenience sampling. [online]. Available at: https://explorable.com/ convenience-sampling (accessed 30 October 2016).

FORREST, R. \& KEARNS, A. 2001. Social cohesion, social capital and the neighbourhood. Urban Studies, 38(12), pp. 2125-2143. https://doi. org/10.1080/00420980120087081

FREUND, B. 2010. Is there such a thing as a post-apartheid city? Urban Forum, 21(3), pp. 283-298. https://doi. org/10.1007/s12132-010-9087-4

GILBERT, A., MABIN, A., MCCARTHY, M. \& WATSON, V. 1997. Low-income rental housing: Are South African 
cities different? Environment and Urbanization, 9(1), pp. 133-144. https:// doi.org/10.1630/095624797101287480

GLASSON, J. \& WOOD, G. 2009. Urban regeneration and impact assessment for social sustainability. Impact Assessment \& Project Appraisal, 27(4), pp. 283-290. https:// doi.org/10.3152/146155109X480358

GOEBEL, A., DODSON, B. \& HILL, T. 2010. Urban advantage or urban penalty? A case study of femaleheaded households in a South African city. Health and Place, 16(3), pp. 573-580. https://doi.org/10.1016/j. healthplace.2010.01.002

GOOSEN, Z. \& CILLEIRS, E.J. 2018. Third places for social sustainability: A planning framework based on local and international comparisons. International Journal of Urban and Civil Engineering, 12(3), pp. 260-264.

GOLD. 2015. Oudtshoorn Local Municipality. The housing crisis and responses in Oudtshoorn. Personal interview, Oudtshoorn, 13 October 2015.

GOVENDER, T., BARNES, J.M. \& PIEPER, C.H. 2011a. Housing conditions, sanitation status and associated health risks in selected subsidized low-cost housing settlements in Cape Town, South Africa. Habitat International, 35(2), pp. 335-342. https://doi.org/10.1016/j. habitatint.2010.11.001

GOVENDER, T., BARNES, J.M. \& PIEPER, C.H. 2011b. The impact of densification by means of informal shacks in the backyards of low-cost houses on the environment and service delivery in Cape Town, South Africa. Environmental Health Insights, 5, pp. 2352. https://doi.org/10.4137/EHI.S7112

GUILLAUME, P. \& HOUSSAYHOLZSCHUCH, M. 2002. Territorial strategies of South African informal dwellers. Urban Forum, 13(2), p. 86-101. https://doi.org/10.1007/ s12132-002-0015-0

GUNTER, A. 2014. Renting shacks: Landlords and tenants in the informal housing sector in Johannesburg South Africa. Urban Challenge (Urbani izziv), 25, pp. S96-S107. https://doi. org/10.5379/urbani-izziv-en-2014-25supplement-007

HENDRICKS, G., SAVAHL, S. \& FLORENCE, M. 2015. Adolescent peer pressure, leisure boredom, and substance use in low-income Cape
Town communities. Social behavior and personality, 43(1), pp. 99-110. https:// doi.org/10.2224/sbp.2015.43.1.99

KLAAREN, J. 2015. Review of governing through crime in South Africa: The politics of race and class in neoliberalizing regimes. Law \& Society Review, 49(2), pp. 551-554. https://doi. org/10.1111/lasr.12148

LATEGAN, L.G. \& CILLIERS, E.J. 2013. South Africa's informal backyard rental sector: Linkages with smart growth and sustainability concepts. Sustainable City 2013. Putrajaya, Malaysia: Wessex Institute of Technology, pp. 303-313. https://doi. org/10.2495/SC130261

LATEGAN, L.G. \& CILLIERS, E.J. 2015. South Africa's informal backyard rental sector through the lens of urban resilience and sustainability. Sustainable Development and Planning 2015. Istanbul, Turkey, pp. 847-857. https://doi.org/10.2495/SDP150711

LATEGAN, L.G. \& CILLIERS, E.J. 2016. Towards more compact South African settlements through informal housing: The case of backyard densification in Bridgton and Bongolethu, Oudtshoorn. Town and Regional Planning, 68. pp.12-26. https://doi. org/10.18820/2415-0495/trp68i1.2

LATEGAN, L.G. 2017. Informality and sustainability: Reflecting on South Africa's informal backyard rental sector from a planning perspective. Ph.D. thesis. North-West University. Potchefstroom, South Africa.

LEMANSKI, C. 2009. Augmented informality: South Africa's backyard dwellings as a by-product of formal housing policies. Habitat International, 33, pp. 472-484. https://doi. org/10.1016/j.habitatint.2009.03.002

LESCH, E. \& ADAMS, A.R. 2016. Couples living with and around alcohol abuse: A study of a farmworker community in the Cape Winelands, South Africa. Social Science \& Medicine, 156, pp. 167-174. https://doi. org/10.1016/j.socscimed.2016.03.030

LIZARRALDE, G. 2011. Stakeholder participation and incremental housing in subsidized housing projects in Colombia and South Africa. Habitat International, 35, pp. 175-187. https:// doi.org/10.1016/j.habitatint.2010.08.001

MAK, M.Y. \& PEACOCK, C.J. 2011. A comparison of case studies in UK,
USA and Australia. $17^{\text {th }}$ Pacific Rim Real Estate Society Conference. Gold Coast, pp. 1-14.

MARAIS, L. \& CLOETE, J. 2014. "Dying to get a house?" The health outcomes of the South African lowincome housing programme. Habitat International, 43, pp. 48-60. https://doi. org/10.1016/j.habitatint.2014.01.015

MATTHEWS, P. \& BESEMER, K. 2015. Social networks, social capital and poverty: Panacea or placebo? Journal of Poverty \& Social Justice, 23(3), pp. 189-201. https://doi.org/10.1332/17 5982715X14448122286274

METH, P. 2013. 'I don't like my children to grow up in this bad area': Parental anxieties about living in informal settlements. International Journal of Urban \& Regional Research, 37(2), pp. 537-555. https://doi. org/10.1111/j.1468-2427.2012.01199.x

MOHAMED, S.I. 2010. Tenant and landlord in South Africa: The book for residential tenancies and the Rental Housing Act. Durban: Organisation of Civic Rights.

MORANGE, M. 2002. Backyard shacks: The relative success of this housing option in Port Elizabeth. Urban Forum, 13(2), pp. 3-25. https://doi. org/10.1007/s12132-002-0011-4

OBREMSKI, H. \& CARTER, C. 2019. Can self-build housing improve social sustainability within low-income groups? The Town Planning Review, 90(2), pp. 167-193. https://doi. org/10.3828/tpr.2019.12

OPP, S.M. 2017. The forgotten pillar: A definition for the measurement of social sustainability in American cities. Local Environment, 22(3), pp. 286-305. https://doi.org/10.1080/13549839.2016. 1195800

PARNELL, S. \& HART, D. 1999.

Self-help housing as a flexible instrument of state control in $20^{\text {th }}$ century South Africa. Housing Studies, 14(3), pp. 367-386. https://doi. org/10.1080/02673039982858

ROBINS, S. 2002. Planning 'suburban bliss' in Joe Slovo Park, Cape Town. Edinburgh: Edinburgh University Press. https://doi.org/10.2307/3556700

RUBIN, M. \& GARDNER, D. 2013. Developing a response to backyarding for South African Local Government Association (SALGA). 
SHAPURJEE, Y. \& CHARLTON, S. 2013. Transforming South Africa's low-income housing projects through backyard dwellings: Intersections with households and the state in Alexandra, Johannesburg. Journal of Housing and the Built Environment, 28(4), pp. 653-666. https://doi.org/10.1007/ s10901-013-9350-9

SHAPURJEE, Y., LE ROUX, A. \& COETZEE, M. 2014. Backyard housing in Gauteng : An analysis of spatial dynamics. Stads- en Streekbeplanning/ Town and Regional Planning, 64, pp. 19-30.

TSHANGANA, A. 2013. Local government position on municipal responses to backyarders and backyard dwellings. Draft Policy Proposal. South African Local Government Association (SALGA), pp. 1-17.

TUROK, I. 2012. Urbanisation and development in South Africa: Economic imperatives, spatial distortions and strategic responses. International Institute for Environment and Development. United Nations Population Fund, pp. 1-66. https://doi. org/10.1177/0269094215614259

TUROK, I. 2016. South Africa's new urban agenda: Transformation or compensation? Local Economy, 31(1-2), pp. 9-27.

WATSON, V. 2009. Strategic literature assessment for informal rental research project. Report to the Social Housing Foundation, pp. 1-26.

WIRE. 2015. Oudtshoorn District Hospital. The health of informal backyard landlords and tenants in Oudtshoorn. Personal interview, Oudtshoorn, 6 October 2015.

WOODCRAFT, S. 2012. Social sustainability and new communities: Moving from concept to practice in the UK. Procedia - Social and Behavioral Sciences, 68, pp. 29-42. https://doi. org/10.1016/j.sbspro.2012.12.204

ZANDREWS. 2013. Oudtshoorn Local Municipality. Health and sanitation in Oudtshoorn. Personal interview, Oudtshoorn, 20 March 2013.

ZWEIG, P.J. 2015. Everyday hazards and vulnerabilities amongst backyard dwellers: A case study of Vredendal North, Matzikama Municipality, South Africa. Jàmbá: Journal of Disaster Risk Studies, 7(1), pp.1-8 https://doi.org/10.4102/jamba.v7i1.210 